\title{
Drug Trafficking and Propaganda: The Image of Drug Trafficking in the Mexican Press 2006-2010
}

\author{
Jacob Bañuelos Capistrán, Fernando Montiel T. \\ Tecnológico de Monterrey, Monterrey, Mexico
}

\begin{abstract}
The aim of this study is to identify and analyze the pattern of visibility of the main actors in the photographic coverage of drug trafficking in six of Mexico's national newspapers. The study was based on a sample of 12,962,000 photographs published from 2006 to 2010. The images were processed by generating a codebook of key categories extracted from the informational context of drug trafficking and the war against drug trafficking. The technique used to explain the newspapers' photographic coverage was the content analysis proposed by Johan Galtung in 1965, in its updated version of 2006. The limitations of the research are time constraints (only four years of President Felipe Calderón's six-year term were analyzed) and information platforms (with the omission of online newspapers, supplements, and additional publications). The study offers an original analysis of the photographic coverage of drug trafficking in the Mexican press. The use of the Galtung Model reveals strong biases and imbalances in the coverage, with a clear tendency to defend the government's position in the analyzed sample.
\end{abstract}

Keywords: drug trafficking, photojournalism, war, actors, Mexico

\section{Introduction}

From December, 2006 to January, 2017, tens of thousands of individuals lost their life in Mexico in the framework of the social crisis known generally as the "war against drug trafficking". In response to this crisis, the number of studies and scholars dedicated to the phenomenon has multiplied, within the various areas of knowledge and aspects of the problem.

The documentary corpus has grown incessantly in almost all relevant topics: civilian victims, arms trafficking, organized crime, and the sociology of violence. Notable studies include Marcela Turati's Fuego cruzado (2006) and Javier Valdez's Los huérfanos del narco (2015) on civilian victims; Magda Coss's Tráfico de armas en México (2012) on arms trafficking; Diego Osorno's El Cártel de Sinaloa (2009) and El cártel incómodo by José Reveles (2010) on the specific analysis of organized crime; and on the sociology of violence, new perspectives, such as El hombre sin cabeza by Sergio González Rodríguez (2009).

The most abundant segment of bibliographical production is journalism, followed by the socio-political analysis of the phenomenon and related policies, and specialized institutions' statistical studies of associated processes. The first group includes outstanding work by reporters, such as Diego Osorno in La guerra de los Zetas (2012), and Anabel Hernández, in the influential piece entitled Los señores del Narco (2012); the second group has El narco: La guerra fallida by Jorge G. Castañeda and Rubén Aguilar (2009); while the third group

Jacob Bañuelos Capistrán, Ph.D., Professor, Department of Communication and Digital Art, Mexico City Campus, Tecnológico de Monterrey, Monterrey, Mexico.

Fernando Montiel T., Associate Professor in the PhD level UNESCO Chair in Ethics and Human Rights in México. 
encompasses publications, like World Drug Report published periodically by the United Nations Office on Drugs and Crime (UNODC, 2010).

As the dynamics of documentary production grow and become more profound, an obvious need arises not only to describe (as in narrative journalism), but also to explain the causes, consequences, and processes of the conflict (as in investigative journalism), and to proceed to design general systems to understand the problem and develop alternative proposals for public policy interventions.

It is precisely in the latter area where an intellectual deficit has been detected. Very few proposals focus on non-violent attention to the crisis, and they have been viewed in only a partial manner, generally marginal in nature. The most widely known proposed alternatives include Movimiento por la Paz con Justicia y Dignidad by Javier Sicilia, and that of Universidad Nacional Autónoma de México (UNAM) called Seguridad y Justicia en Democracia, both from 2011; as well as the sector recommendations of Instituto para la Seguridad y la Democracia AC (INSYDE, 2011). Further information in this respect can be seen in the design and subsequent disarticulation of Programa Nacional para la Prevención Social de la Violencia y la Delincuencia, created during the term of President Enrique Peña Nieto with a budget of slightly more than two billion pesos (approximately 100 million dollars); in 2017, the same government that developed the program eliminated its funding.

The aim of the current study is to identify and analyze the pattern of visibility of the main actors in the photographic coverage of drug trafficking, as published in six national newspapers. Due to the dimensions of drug trafficking and the nature of its actors, the design and implementation of integrated policies are of notable difficulty. Thus, the model used as a frame of reference is that of Montiel (20121) - a model that presents 36 recommendations in six sectors to study and deal with drug trafficking and related policies. Based on this model, the current study focuses on two recommendations from Sector 5 on Cobertura del Conflicto en México: Number 25 (Encourage prestige based on professionalism) and Number 28 (Discourage unprofessional coverage).

\section{Social Conflict and Journalistic Coverage}

The category of Professionalism is evidently ambiguous in the original model, and therefore requires clarification. In the journalistic coverage of events in public safety and criminal justice, Professionalism can be addressed from various angles: the deontological frameworks of journalism (classical frameworks as well as frameworks adjusted to the crisis) suggested by Lara Kahr and Barata (2004; 2009; 2011); the studies from the project of "Violencia y Medios" of the Instituto para la Seguridad y la Democracia A.C. (http://www.insyde.org.mx); or the institutional self-regulation of media as in the case of Acuerdo para la cobertura informativa de la violencia en México, a proposal gestated, established, and then forgotten-a failed agreement as defined by Lozano (2016).

In the current study, the specific framework for understanding Professionalism will follow the model introduced by Galtung and Ruge in 1965: A model developed not only for the projection of trends and the news potential of events and content, but also for the evaluation of coverage. Additional work by Galtung can be seen on journalistic coverage, the media, and conflict and peace $(2002 ; 2003 ; 2004 ; 2008 ; 2009 ; 2010 ; 2013$; Galtung \& Inayatullah, 1979, 1995, 1997).

According to the model's developers, the Professionalism of news coverage (by a particular reporter or the media in general) regarding any topic of public interest-such as drug trafficking in Mexico - can be determined as a function of the balance of its contents, according to the following factors (see Table 1). 
Table 1

Factors and Variables of Balance in Journalistic Content

\begin{tabular}{llll}
\hline & Factors & Variables & \\
\hline 1. & Social affiliation of actors & Elite & Non-elite \\
2. & Global affiliation of place of occurrence & Elite & Non-elite \\
3. & Nature of phenomenon & Personal & Structural \\
4. & Nature of event & Positive & Negative \\
\hline
\end{tabular}

Note. Source: Galtung, Lynch, and Mc. Goldrick (2006).

According to the authors of the model's more recent version of 2006, the relation between Professionalism and Balance is directly proportional. In other words, the greater the balance in the coverage of each variable factor is, the greater the professionalism of the journalistic coverage of the media and reporters is.

To illustrate the manner that imbalance acknowledges bias, which is either unconscious (cultural) or conscious (ideological or propagandistic), Galtung, Lynch, and Mc. Goldrick (2006) generated a system of indicators of value for each variable, in each factor (see Table 2).

Table 2

News Potential and Bias of Coverage

\begin{tabular}{lll}
\hline Factors & Value & \\
\cline { 2 - 3 } & +1 & Non-elite \\
\hline 1. Social affiliation of actors & Elite & Non-elite \\
2. Global affiliation of place of occurrence & Elite & Structural \\
3. Nature of phenomenon & Personal & Negative \\
4. Nature of event & Positive & \\
\hline
\end{tabular}

Note. Source: Galtung, Lynch, and Mc. Goldrick (2006).

Through weighting, Galtung et al. (2006) offered a numerical scale to rate the news potential of a certain event and the clarity of bias in coverage, in which " 4 " indicates the maximum news potential and "0" no potential. Thus, an elite actor $(+1)$, in an elite nation $(+1)$ who experiences a personal phenomenon $(+1)$ as part of a negative event $(+1)$ will have the maximum news potential versus a positive event $(0)$ that occurs in a structural dimension (0) in a peripheral nation (0) to an ordinary person (0). The structural level refers to the architecture of a society, and is the circuit in which interaction among institutional entities is studied (Galtung \& Inayatullah, 1995).

Based on the above, the current study has returned to the model of Galtung and Ruge (in its most recent version of 1965) to analyze the content of the Actor variable in a sample of 12,962 photographs that were published in six of Mexico's national newspapers between December, 2006 and June, 2010. The images refer to the conflict of drug trafficking in general and to the "war against drug trafficking" in particular.

The specific intent was to define the ideological and propaganda biases that occurred in the coverage of drug trafficking in the analyzed newspapers. Also, study was the degree of professionalism-in terms of informational balance - to identify patterns of behavior in the media's coverage of the Actor variable, in relation to other variables.

Both the sample and the variables in the study were defined, integrated, and systematized according to the methodology described below. 


\section{Method}

The current study used a sample of newspaper articles with photographs from six national newspapers in Mexico: El Universal, El Sol de México, Milenio, Reforma, La Jornada, and Excelsior. The initial sample consisted of 25,000 articles obtained from a search based on two criteria: "narcotráfico" (drug trafficking) and "guerra del narco" (narco war) from December, 2006 to June, 2010, in the databases of the media monitoring firm, Eficiencia Informativa.

The defined time period corresponds to the beginning of the "war against drug trafficking" in late 2006, and extends to the conflict's critical point of 2010. In this sense, the sample covers the first stage of a still active conflict and analyzes the coverage patterns of photographic information in its earliest stages. Such patterns may or may not be active at the present time.

The initial sample of 25,000 news items with photographs was filtered for reasons of normalization and stabilization, according to the criteria of analysis established in the specifically created codebook; taken into consideration were the context of each image, the news item, and the newspaper. As a result of this filter, the sample was reduced to 12,962 news items with photographs, which form the corpus analyzed in this study.

The codebook contains a table of variables or categories of analysis that were applied for each photograph in the context of the accompanying news item and the place occupied in the printed newspaper. The analyzed variables were: newspaper, month, year, topic of news item, main content of image, context of image (function of caption - anchor or relay), relevance of photo to copy, main actors in image, individuals identified in caption, source of image, location of image in the newspaper, point of view, layout, black and white, color. The level of measurement of each variable was nominal, except for the year and month, which were ordinal.

A numbered operational definition was established for each variable: a definition described in turn by detailed specifications. Both the codebook and the numerical synthesis expressed in percentages for each case can be consulted at http://bit.ly/2qpXUyK.

The construction of the codebook was based on categories of analysis taken from the informative context of "drug trafficking" and "narco war" predominant in the designated newspapers from 2006 until 2010. The categories include the main actors, the topics, the image content, and the individuals identified in the captions.

The basis for analyzing the photographs was the model of interpretative analysis developed by Felici (2007, pp. 169-218) to describe categories of photographs, such as main actors, individuals identified in the image, source of the image, location of the image in the newspaper, point of view, layout, and the color of the published photograph (black and white or in color). The context of the photograph and its relevance in relation to the copy, as well as the relation between the caption and the image, were analyzed based on the categories of anchor and relay as proposed by Barthes (1989, p. 37).

The data were analyzed through descriptive statistics (Cazau, 2006); cross tabulation and graphs were produced with the RawGraphs (see http://rawgraphs.io/) software. The actor variable was considered to be the dependent variable, and its behavior would be studied in relation to the variables: year, newspaper, topic, identified individuals, content, location, and context as independent variables.

\section{Analysis of Results}

The Actor variable, the main analytical focus, was studied through its interaction (cross tabulation) with seven variables divided into three different groups. The variables' organization into groups corresponds to 
aspects in common that permit a more detailed, supplementary reading. The objective was to determine specifically which actors appear in the published photographs and how this variable behaved in the light of the other variables, according to the model by Galtung et al. (2006).

\section{Group 1}

Group 1 includes the two most relevant variables for locating the analyzed information in time and space (year and newspaper variables).

Actor-year. During the entire sample period (2006-2010), 77.5 percent of the photographs showed in a basic and systematic manner the same pattern of five actors. This pattern, which we shall call the Pattern of Actor Visibility, was government authorities ( 25.2 percent) with the highest percentage in all instances, followed by police (17.9 percent), members of the military (17.6 percent), Mexican politicians (9.3 percent), and drug traffickers ( 7.5 percent), with variations by year.

The corpus of analysis showed that although 2010 was the most violent in the "war against drug trafficking" newspapers in 2007, 2008, and 2009 published more images of the topic (33.7 percent, 30.4 percent, and 19.8 percent respectively, all greater than the 14.1 percent of 2010). Few images were produced in 2006 since the "war against drug trafficking" was declared at the end of that year.
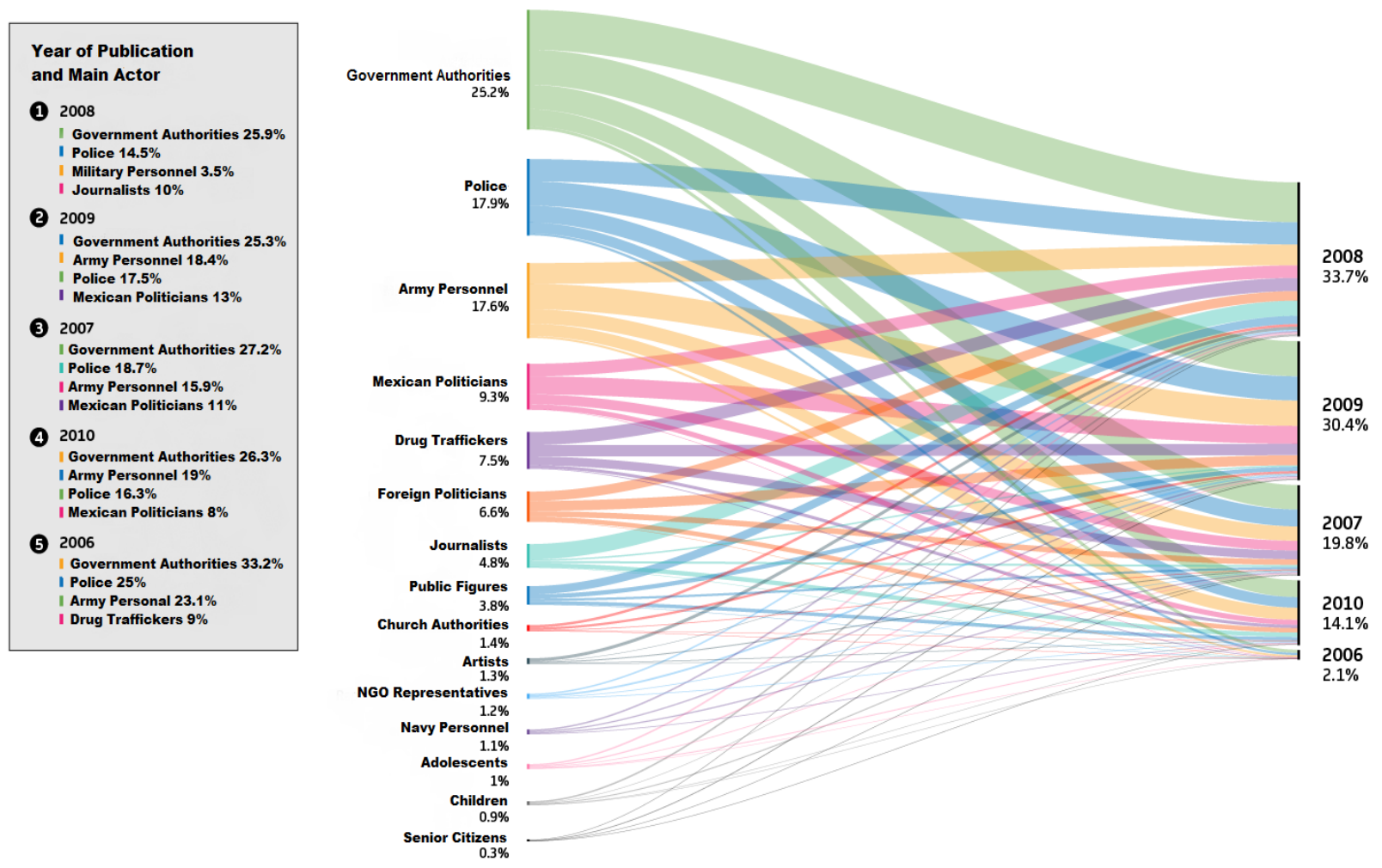

Figure 1. Year of publication and main actor (Source: Own elaboration, 2017).

Actor-newspaper. Of the total number of photographs considered, Milenio published 23 pèrcent; $E l$ Universal published 22.8 percent; Excélsior published 19.6 percent; El Sol de México published 16.5 percent; Reforma published 12.8 percent; and La Jornada published 5.3 percent. In the actor-newspaper relationship, the Pattern of Actor Visibility remained constant on the whole, although variations were once again detected among newspapers. 
In an individual manner, El Universal, Milenio, and Reforma were the newspapers that stayed the closest to the Pattern of Actor Visibility in their photographic coverage of the war against drug trafficking (with minor variations in each publication). El Sol de México maintained the Pattern of Actor Visibility in general terms (except for showing the political class more than armed actors), and Excélsior is outstanding for having journalists as the most visible actor (19.6 percent). La Jornada is notable because of a quantitative aspect of its coverage; although it adhered to the Pattern of Actor Visibility, it published only 5.3 percent of the analyzed photographic sample, less than one-half of the publication that follows it in percentage terms (Reforma with 12.8 percent).


Figure 2. Newspaper and main actor (Source: Own elaboration, 2017).

\section{Group 2}

Group 2 includes the variables that contribute the most to the discursive content of the photographs under consideration (topic, identified individuals, and content variables).

Actor-topic. The actor-topic relationship refers to the topic of the newspaper article to which the photograph is attached. In this relationship, slightly more than one-half of the topics (55.5 percent) are in five areas: Statements by government authorities is the main topic with 21.8 percent, followed by government actions (regarding drug trafficking and organized crime) with 15.6 percent, only drug trafficking with 6.6 percent, journalists' opinions with 6.3 percent, and military operations with 5.2 percent.

In this relationship, the correspondence between actors and topics of direct association (for example, journalists and journalists' opinions) is obvious. Yet at a slightly deeper level, one finds the outstanding presence, weight, and uniformity (almost monolithic in the case of government authorities, and more disperse but equally solid in the case of members of the military) of government topics expressed by government actors. 
Their frequency is much higher than the remaining topics and actors, which tend to become atomized upon segmentation.

\begin{tabular}{|c|c|}
\hline \multicolumn{2}{|c|}{$\begin{array}{l}\text { Topic of Image } \\
\text { Main Actor }\end{array}$} \\
\hline (1) & $\begin{array}{l}\text { Statements by Government } \\
\text { Authorities } 21.8 \% \\
\text { | Government Authorities } 53.5 \% \\
\text { | Miltary Personnol } 16.1 \% \\
\text { | Moxican Poiliciains } 13.9 \% \\
\text { | Palice } 5.8 \%\end{array}$ \\
\hline (2) & $\begin{array}{l}\text { Government Actions (Drug Traffleking } \\
\text { and Organizad Crimo) } 15.6 \%\end{array}$ \\
\hline & $\begin{array}{l}\text { I Govemment Authorities } 32.6 \% \\
\text { I Police } 11.7 \% \\
\text { I Miltary Personnel } \quad 22.0 \% \\
\text { I Mexican Polticians } 13.2 \%\end{array}$ \\
\hline (3) & $\begin{array}{l}\text { Only Drug Trafficking } 6.6 \% \\
\text { I Govemment Authorities } 33.26 \% \\
\text { I Mexican Politicians } 20.61 \% \\
\text { I Police } 16.86 \% \\
\text { I Miltary Personnel } 8.67 \%\end{array}$ \\
\hline (4) & $\begin{array}{l}\text { Journalists' Opinions } 6.3 \% \\
\text { I Joumalists } 69 \% \\
\text { I Government Authorities } 14.6 \% \\
\text { I Drug Traffickers 4.1\% } \\
\text { I Mexican Politicians } 3.3 \%\end{array}$ \\
\hline (5) & Military Operations 5.2\% \\
\hline & $\begin{array}{l}\text { I Military Personnel } \quad 64.8 \% \\
\text { I Police } 18.9 \% \\
\text { I Drug Traffickers } 6.4 \% \\
\text { I Government Authorities } 5.6 \%\end{array}$ \\
\hline 6 & Crimes $4.9 \%$ \\
\hline & $\begin{array}{l}\text { I Government Authorities } 22.8 \% \\
\text { I Police } 45.3 \% \\
\text { I Miltarv Personnel } 18.9 \% \\
\text { I Mexican Politiciains } 3.6 \%\end{array}$ \\
\hline 7 & International Opinions $4.9 \%$ \\
\hline & $\begin{array}{l}\text { I Foreign Politicians } 55.7 \% \\
\text { I GovernmentA Authortities } 22.5 \% \\
\text { I Public Figures } 4.9 \% \\
\text { I Mexican Politicians } 4.6 \%\end{array}$ \\
\hline
\end{tabular}

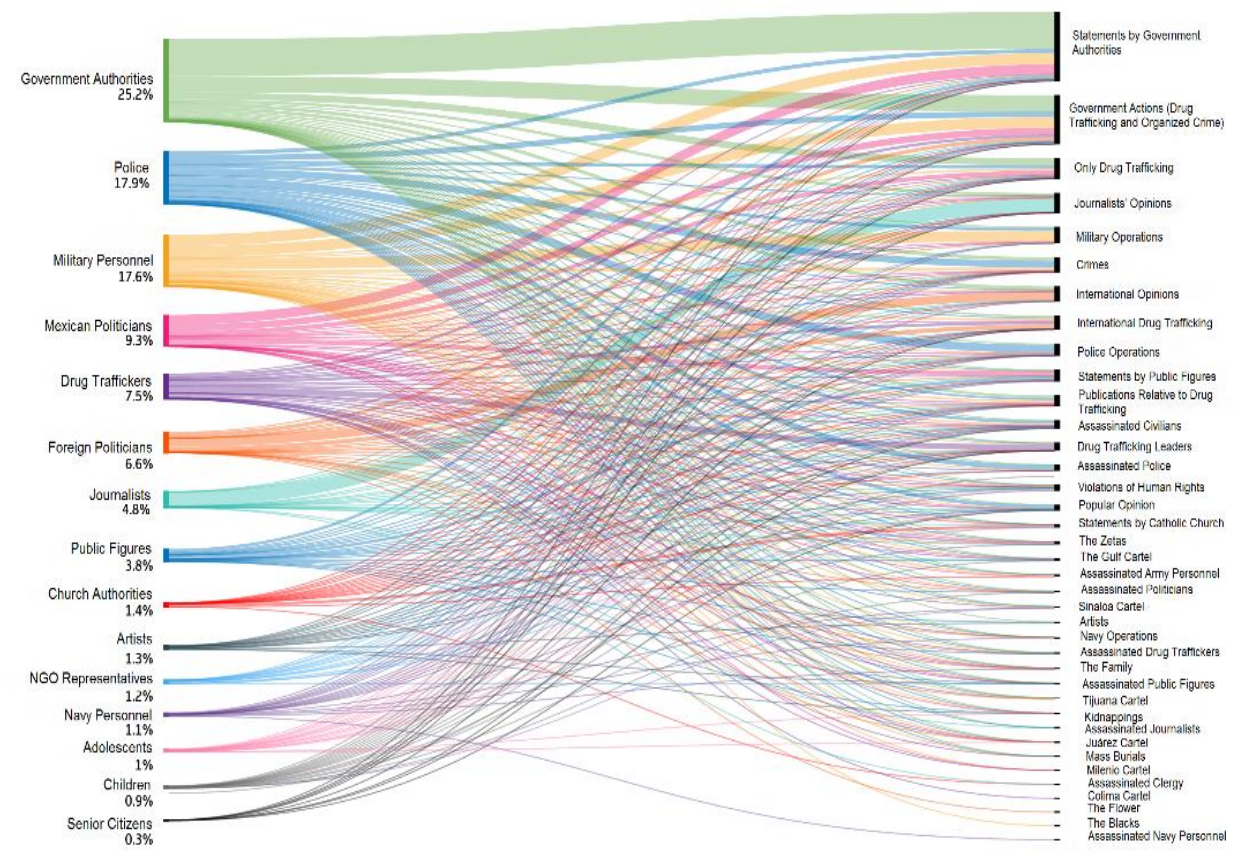

Figure 3. Topic of image and main actor (Source: Own elaboration, 2017).

Actor-identified individuals. The sample showed that in 70.3 percent of the published photographs, the photographed individuals were identified, versus 29.7 percent that did not identify the photographed individuals in the caption.

The actor-identified individual relationship has differentiated coverage if observed in terms of type of actor. According to the Pattern of Actor Visibility, civilian actors are highly transparent because they are identifiable in the photographs (government authorities with 33.9 percent, Mexican politicians with 13.1 percent, and foreign politicians with 8.3 percent), while armed actors of the state (police with 8.7 percent and members of the military with 8.2 percent) lack transparency. Of the actors not identified in the photographs, 71.4 percent are members of the military or police. The only exception (as a civilian, non-governmental but armed actor) is drug traffickers, representing 9.1 percent of the identifiable actors in the photographs.

Actor-content. The evident correspondence indicated above in the actor-topic relationship, is repeated in the actor-content relationship (main subject of the photograph). An outstanding factor in this relationship is that the contents follow the Pattern of Actor Visibility very closely. In the sample under consideration, 60 percent of the discursive content is directly proportional to the Pattern of Actor Visibility: Official statements by government representatives is the most frequent content with 14.8 percent, followed by military operations with 12.4 percent, references to government figures with 10.9 percent, police operations with 8.7 percent, Mexican politicians with 6.7 percent, and official statements by President with 6.5 percent of the total. 


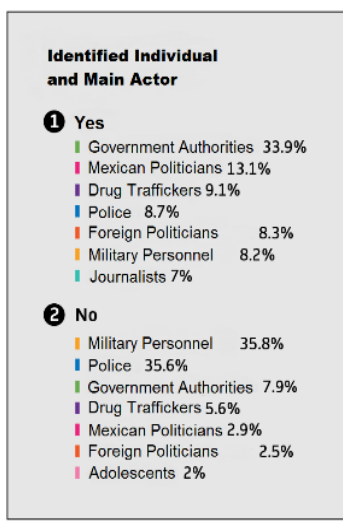

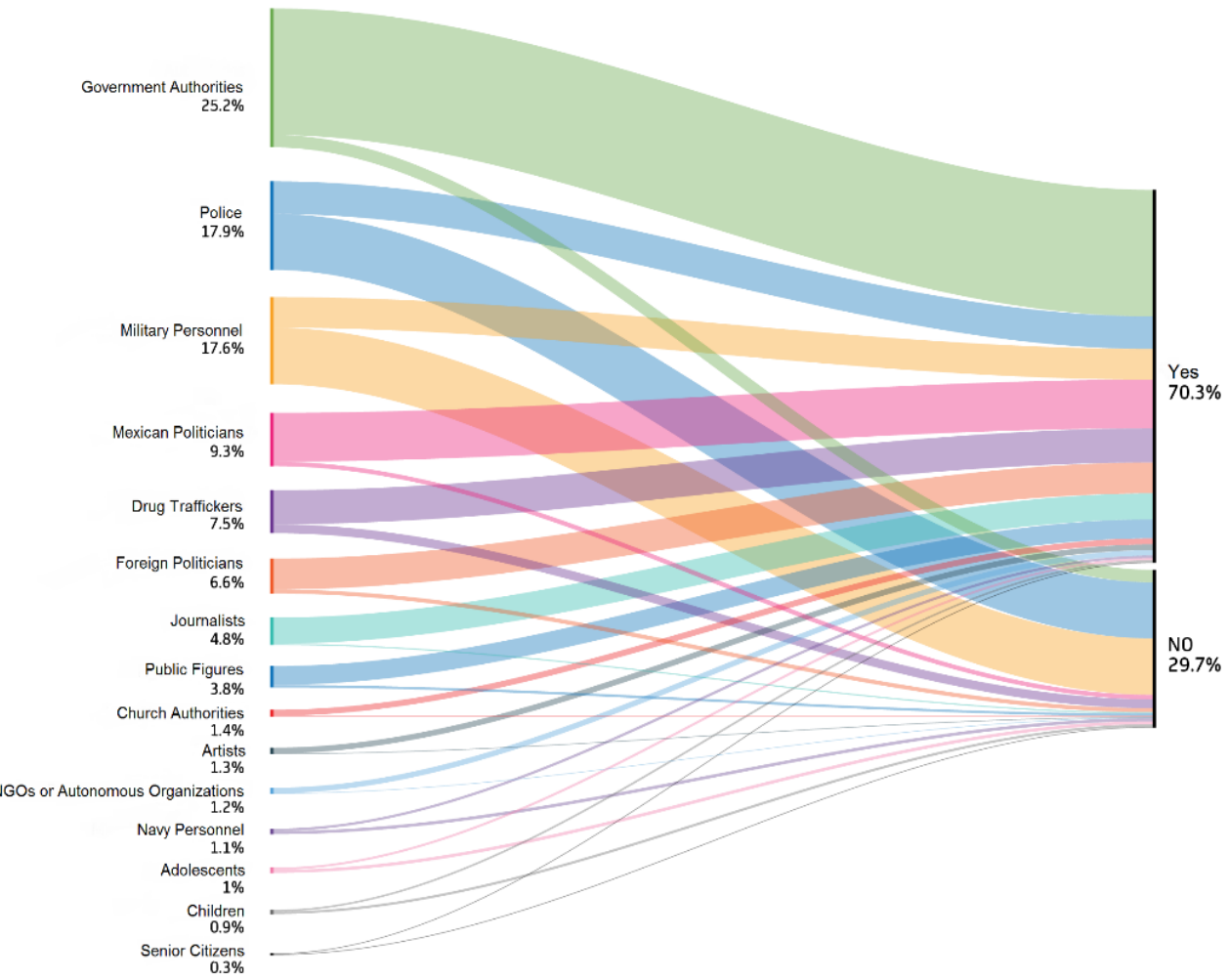

Figure 4. Identified individual and main actor (Source: Own elaboration, 2017).

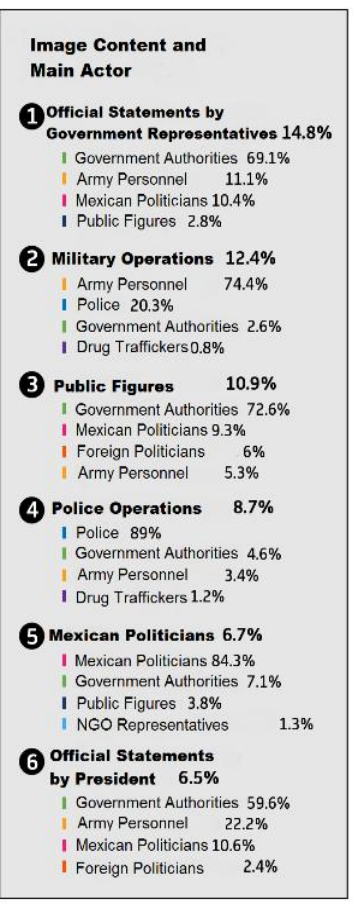

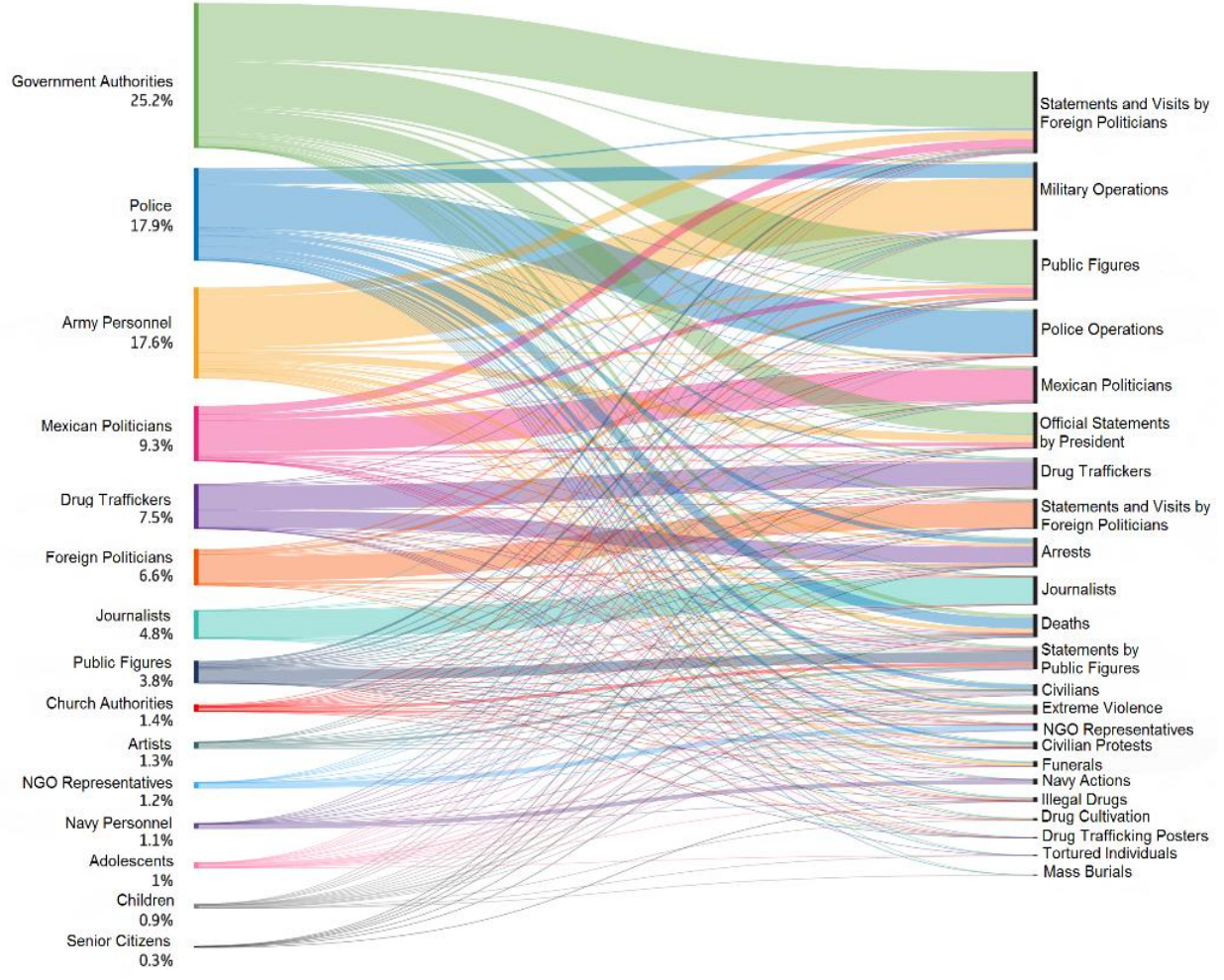

Figure 5. Image content and main actor (Source: Own elaboration, 2017). 


\section{Group 3}

Group 3 considered the variables that contribute to the analysis of the media and its editorial policies (actor-location and actor-context variables).

Actor-location. In the actor-location relationship, the main location of the photographs was indoors settings ( 84.6 percent of the sample), followed by the front page (13.8 percent), and only a small proportion on the back page (1.6 percent).

The behavior of the Pattern of Actor Visibility is maintained in this relationship (although naturally in different proportions). The tendency is a higher frequency of government authorities as the most represented actor in indoor settings and on the front page ( 25.7 percent and 30.8 percent respectively), followed by police in indoor settings (17 percent) and members of the military on the front page (16.4 percent).

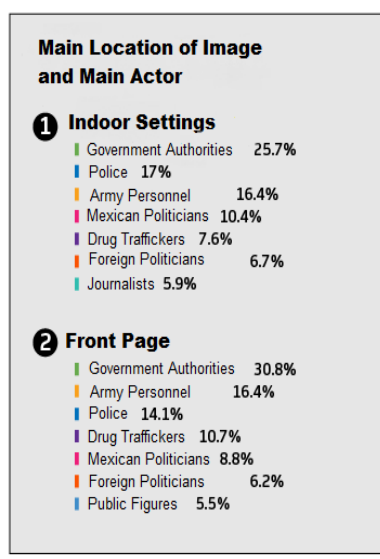

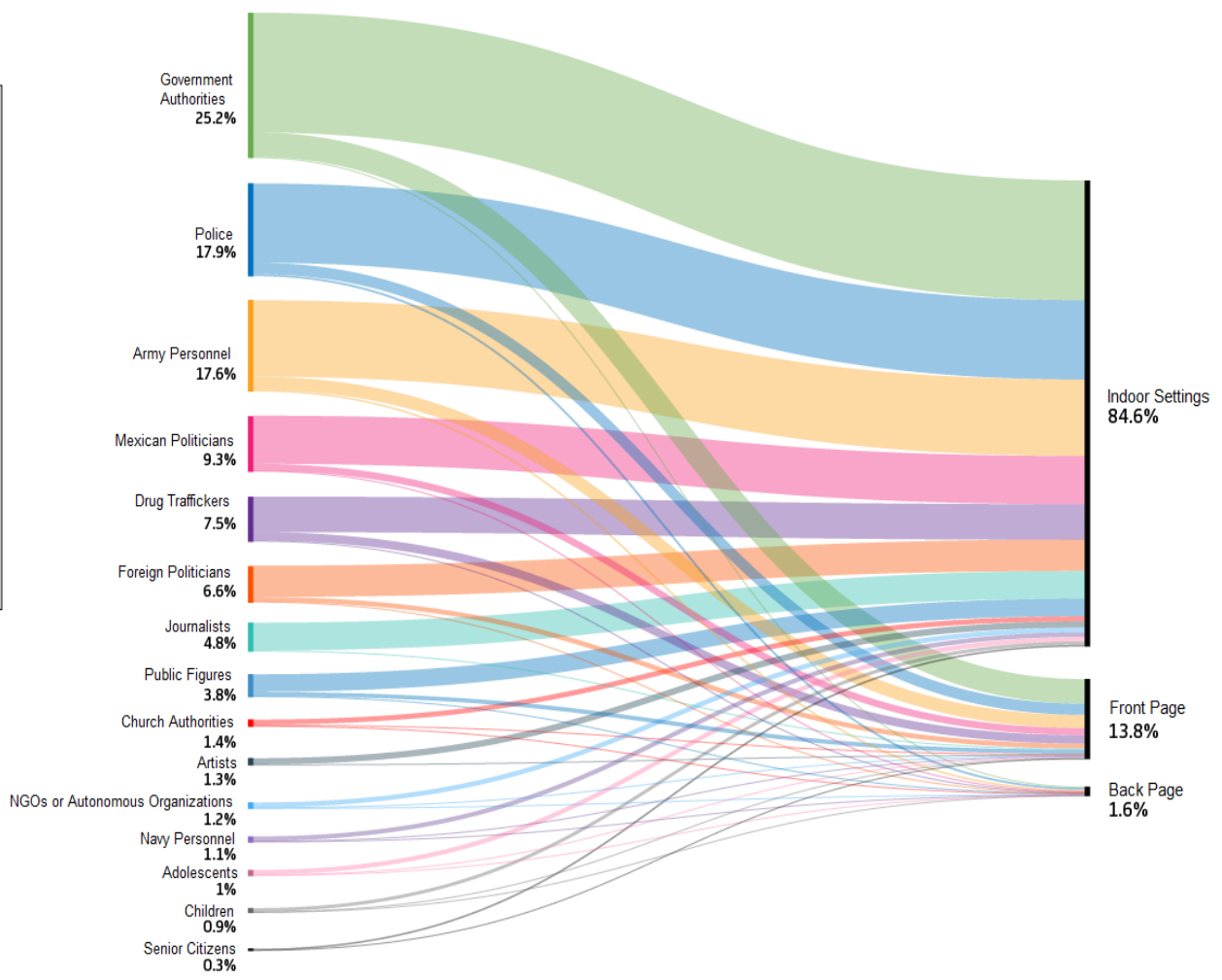

Figure 6. Main location of the image and main actor (Source: Own elaboration, 2017).

Actor-context. The actor-context relationship of the analyzed photographs reveals that the function of the photograph and its caption in the article was primarily informative (71.1 percent of the total). Only one-third (28.9 percent) had a function of editorial accompaniment, in which the caption played an interpretative role.

The Pattern of Actor Visibility in this relationship was also constant and stable in all cases, although slightly more than one-half (53.8 percent) of all the photographs with informative captions correspond to government actors (government authorities with 25.2 percent, members of the military with 12.7 percent, and police with 12.7 percent). The percentage of interpretative captions of these same actors totals 72.9 percent, showing that the most visible Actors with informative and interpretative captions are armed government actors, rather than civilian authorities. 


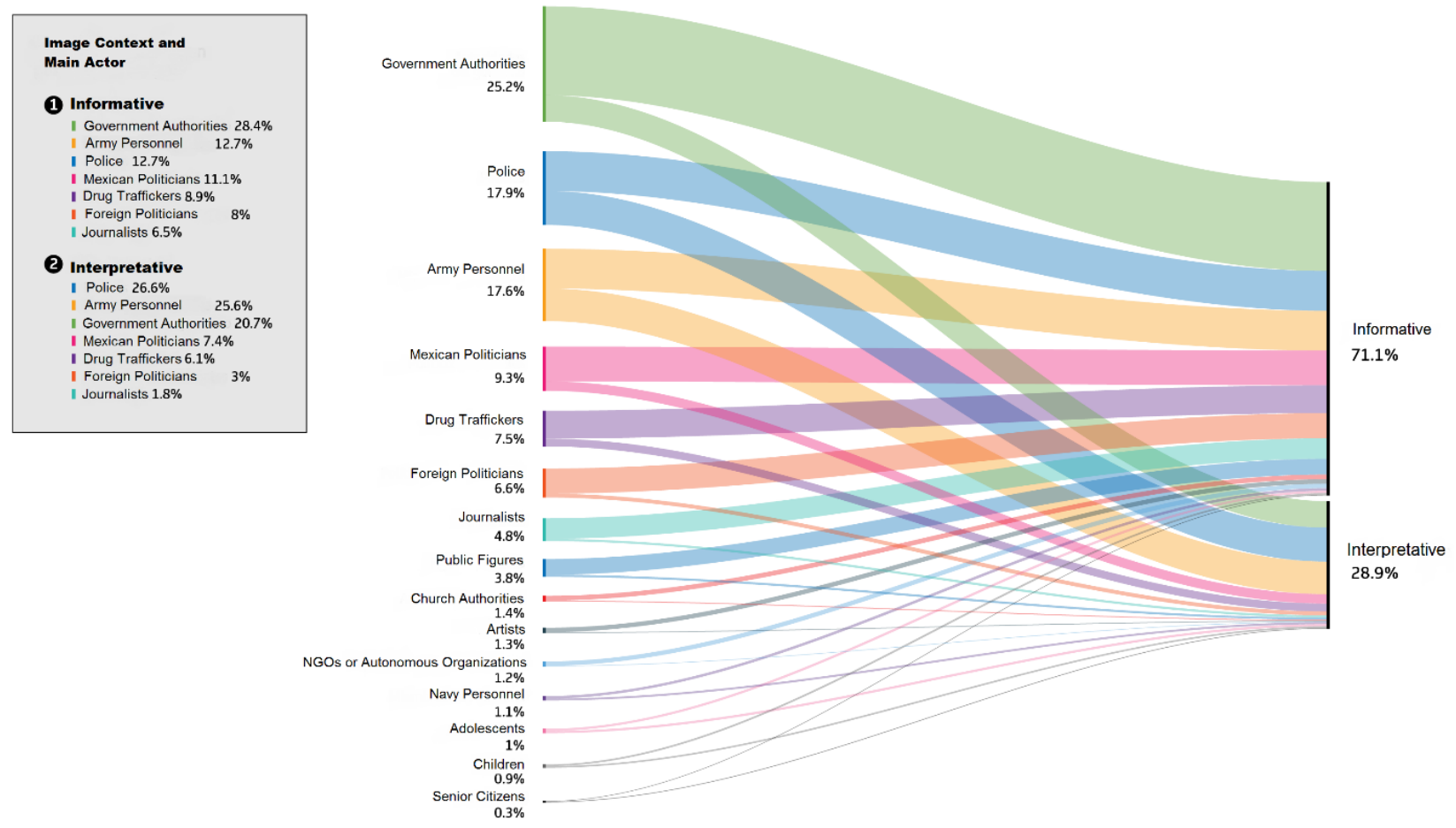

Figure 7. Image context and main actor (Source: Own elaboration, 2017).

\section{Discussion}

Since the Pattern of Actor Visibility included elite actors (such as high government officials) and armed actors (such as police, members of the military, and drug traffickers), the non-elite and unarmed actors (such as members of non-governmental organizations) tended to be invisible. This was a constant in the photographs from all years and in all the newspapers under study. Thus, the behavior of the Actor variable in Group 1 (its relationship with the newspaper and year variables, which are related to the information's location in time and space), confirms the theory of Galtung et al. (2006) with respect to news potential and bias of coverage. The newspapers under study make visible in a systematic and almost homogeneous manner-with slight biases by newspaper or by year - the same elites (particularly government) and armed sectors in their coverage of drug trafficking.

The variables in Group 2-those related to discursive content (topic, identified individuals, and content) confirm the initial findings. The topics that the newspapers illustrate photographically with greatest frequency are those that refer to government events and their actors, followed by topics that deal directly with actors that employ violence (drug traffickers and police/military operations). In this sense, the identification of government actors in the photographs is inversely proportional to their armed condition; i.e., the members of the political class are more identifiable than the police and members of the military. This situation newly validates another aspect of the model by Galtung et al. (2006) that political actors are visualized as individuals, while the armed entities of the state are assumed photographically as structures. Therefore, political actors are more transparent than the armed entities of the state. The previously mentioned exception (drug traffickers) also confirms the model of reference: Since they are covered as elite individuals with a negative role, they have high transparency in the photographs and high news potential. 
The study's findings regarding the variables of Group 3 (Location and Context) are consistent with the proposals of Galtung et al. (2006) in terms of the biases of news coverage. Political elites and violent actors have the greatest weight in the editorial considerations of the newspapers under study. Government authorities are the most represented actor, followed on the front page by members of the military, and in indoor settings by Police. With reference to Context, government images and voices are more present in cases where interpretation is required, than in contexts that are merely informative. While not definitive, this trait points not only to government bias but also to military bias (since armed actors have greater representation than unarmed government actors), and could affect the results of interpretation.

\section{Conclusions and Future Studies}

Based on the model by Galtung et al. (2006), the photographic coverage of "the drug trafficking" conflict and "the war against drug trafficking" in the printed version of the Milenio, El Universal, Reforma, La Jornada, Excélsior, and El Sol de México newspapers in the period from 2006 to 2010, points to a systematic informative imbalance that makes visible one set of actors to the detriment of the other actors. As indicated in the model of reference for the analysis of news potential, the most represented actors are those that pertain to the government sector: representatives of the government, police, and military. Those not pertaining to the government sector are made visible when they are individuals and not armed groupings (structures) that have a potentially negative role in the dynamics of the conflict (drug traffickers).

The conclusion is that during the period under consideration, and based on the studied newspapers and the defined variables, the photographic coverage of the drug trafficking conflict has complied with a propagandistic function clearly inclined to make visible the government actors, positions, and discourses, rather than and in detriment to all other actors, positions, and discourses.

Future research may elucidate the reason that the deadliest year (2010) in the conflict, during the period of study, was not necessarily the year of greatest photographic coverage. Other case studies may address the differences of the editorial policies of the newspapers under consideration, in order to explain the diversity of photographic coverage (such as the comparatively low number of photographs published in La Jornada during the period of study). Subsequent work may also investigate the reasons (technical, political, etc.) for the different representations of each actor.

\section{References}

Barthes, R. (1989). Lo obvio y lo obtuso (The obvious and the obtuse). Barcelona: Paidós.

Castañeda, J. (2017). Tropas, letalidad, y violencia (Toops, loyalty, and violence). El Financiero, February, p. 8.

Castañeda, J., \& Aguilar, R. (2009). El narco: La guerra fallida (The narco: The failed war). México: Punto de Lectura.

Cazau, P. (2006). Fundamentos de estadística (Fundamentals of statistics). Retrieved from http://bit.ly/2qpvi7K

Coss, M. (2012). Tráfico de armas en México (Arms trafficking in Mexico). México: Grijalbo.

Felici, J. (2007). Cómo se lee una fotografía: Interpretación de la mirada (How do you read a photo: Interpretation of the gaze). Madrid: Cátedra.

Galtung, J. (1979). Paper in methodology: Theory and methods of social research, essays in methodology (Vol. II). Copenhagen: Christian Ejlers.

Galtung, J. (1995). Investigaciones teóricas: Sociedad y cultura contemporáneas (Theoretical research: contemporary society and culture). Madrid: Tecnos.

Galtung, J. (2002). Searching for peace: The road to Transcend. London: Pluto Press.

Galtung, J. (2003). Paz por medios pacíficos: Paz y conflicto, desarrollo y civilización (Peace through peaceful means: Peace and conflict, development and civilization). Bilbao: Gernika Gogoratuz. 
Galtung, J. (2004). Trascender y transformar: Una introducción al trabajo de conflictos (Transcending and transforming: An introduction to conflict work). México: Quimera-UNAM.

Galtung, J. (2008). La meta es el camino: Gandhi hoy (The goal is the path: Gandhi today). México: TUP.

Galtung, J. (2009). 50 años, 25 paisajes intelectuales explorados (50 years, 25 intellectual landscapes explored). México: TUP.

Galtung, J. (2010). Launching peace studies: The first PRIO Years: Strategies, findings, implications. México: TUP.

Galtung, J. (2013). A theory of peace: Building direct, structural and cultural peace. México: Transcend University Press (TUP).

Galtung, J. (2016). Transformación de conflictos por medios pacíficos: El Método Transcend (Transformation of conflicts through peaceful means: The Transcend Method). Proceedings from the UNESCO Chair of Ethics and Peace Culture for the Scope of Human Rights, México.

Galtung, J., \& Inallatulluh, S. (1997). Macrohistory and Macrohistorians: Perspectives on individual, social and civilizational change. Westport: Praeger Publishers.

Galtung, J., \& Inayatullah, S. (1997). Macrohistory and Macrohistorians: Perspectives on individual, social and civilizational change. Westport: Praeger Publishers.

Galtung, J., \& Ruge, M. (1965). The structure of foreign news: The presentation of the Congo, Cuba and Cyprus Crisis in four Norwegian newspapers. Journal of Peace Research, 2(1), 64-91.

Galtung, J., Lynch, J., \& Mc. Goldrick, A. (2006). Reporteando conflictos: Una introducción al periodismo de paz (Reporting conflicts: An introduction to peace journalism). México: TUP.

González Rodríguez, S. (2009). El hombre sin cabeza (The man without head). México: Anagrama.

Hernández, A. (2012). Los señores del Narco (The lords of Narco). México: Penguin Random House.

Lara, M., \& Barata, F. (2004). Medios y violencia: Seguridad pública, noticias y construction del medio (Media and violence: Public safety, news and construction of the environment). México: Instituto para la Seguridad y la Democracia A.C./CIDE.

Lara, M., \& Barata, F. (2009). Nota(N) Roja: Historia de un género y una nueva manera de informar (Note(N) Red: Story of a genre and a new way of informing). México: Debate.

Lara, M., \& Barata, F. (2011). Periodismo: Recurso social para la paz (Journalism: Social resource for peace). México: Friedrich Ebert Stiftung.

Lozano, J. (2016). El acuerdo para la cobertura informativa de la violencia en México: Un intento fallido de autorregulación (The agreement for the informative coverage of violence in Mexico: A failed attempt at self-regulation). Comunicación y Sociedad, $26,13-42$.

Montiel, F. (2012). Morir por nada: Narcotráfico y violencia de estado en México (Die for nothing: Drug trafficking and state violence in Mexico). México: Lectorum.

Osorno, D. (2009). El Cártel de Sinaloa (The Sinaloa Cartel). México: Grijalbo.

Osorno, D. (2012). La guerra de los Zetas (The war of the Zetas). México: Grijalbo.

Reveles, J. (2010). El cártel incómodo (The uncomfortable cartel). México: Grijalbo.

Secretaría de Gobernación (Ministry of the Interior). (2006). Programa nacional para la prevención social de la violencia y la delincuencia (National program for the social prevention of violence and crime). México: Secretaría de Gobernación (Ministry of the Interior).

Turati, M. (2006). Fuego cruzado (Crossfire). México: Grijalbo.

United Nations Office on Drugs and Crime. (2010). World Drug Report. Retrieved from http://bit.ly/2rke1iA

Valdez, J. (2015). Los huérfanos del narco (The orphans of the narco). México: Aguilar. 